\title{
Proximate composition, amino acid profile, carbohydrate and mineral content of seed meals from four safflower (Carthamus tinctorius L.) varieties grown in north-eastern Morocco
}

\author{
Farid Mansouri ${ }^{1, *}$, Abdessamad Ben Moumen ${ }^{1}$, Gaetan Richard $^{2}$, Marie-Laure Fauconnier ${ }^{2}$, \\ Marianne Sindic ${ }^{3}$, Ahmed Elamrani ${ }^{1}$ and Hana Serghini Caid ${ }^{1}$ \\ ${ }^{1}$ Laboratory of Plants and Microorganisms Biology, Faculté des Sciences Oujda - Université Mohammed Premier, BP-717, \\ 60000 Oujda, Morocco \\ ${ }^{2}$ General and Organic Chemistry Unit, Gembloux Agro-Bio Tech - Université de Liège, Passage des Déportés 2, 5030 Gembloux, \\ Belgium \\ 3 Analysis Quality and Risk Unit, Laboratory of Food Quality and Safety, Gembloux Agro-Bio Tech - Université de Liège, \\ Passage des Déportés 2, 5030 Gembloux, Belgium
}

Received 18 November 2017 - Accepted 29 December 2017

\begin{abstract}
The purpose of this study is to complete our work on the characterization of four safflower varieties produced in the oriental region of Morocco by determining the composition of their meals. This characterization was carried out by analyzing proteins, amino acids, fibers, carbohydrates and mineral elements. The results show that the protein content varies in a range of 17.06-27.05\%, fibers $63.45-69.97 \%$, carbohydrates $12.40-17.07 \%$ and ash $3.11-3.60 \%$ on dry weight basis. The most abundant amino acid in the studied safflower meals is glutamic acid (3.19-3.89\% of dry matter), while lysine and methionine are the least abundant. Cellulose and hemicellulose are the most representative fibers $(28.16-31.35 \%$ and $21.04-21.68 \%$ of dry matter, respectively). The main carbohydrate is xylose, whose content varies between $10.56-14.31 \%$ of dry matter. The results also show that the studied safflower meals constitute a good source of potassium $\left(6.32-9.51 \mathrm{~g} \mathrm{~kg}^{-1}\right.$ of dry matter), phosphorus $\left(2.35-4.60 \mathrm{~g} \mathrm{~kg}^{-1}\right)$, magnesium $\left(2.25-4.25 \mathrm{~g} \mathrm{~kg}^{-1}\right)$ and calcium $\left(1.53-1.72 \mathrm{~g} \mathrm{~kg}^{-1}\right)$. Amongst the identified microelements, iron is the major element in all the analyzed samples $\left(53-125 \mathrm{mg} \mathrm{kg}^{-1}\right)$. Moreover, the majority of the studied analytical parameters were strongly influenced by the cultivar factor $(p<0.05)$. In view of these analyses and pasture shortage, especially during the dry seasons in Morocco, the meal obtained from oil extraction from safflower seeds can be upgraded by the formulation of new animal feed products in this region.
\end{abstract}

Keywords: safflower / meal quality / carbohydrates / amino acids / minerals

Résumé - Caractérisation biochimique de tourteaux de quatre variétés de carthame (Carthamus tinctorius L.) cultivées dans la région oriental du Maroc. La présente étude vise à compléter nos travaux sur la caractérisation des semences de carthame produites dans la région orientale du Maroc par la détermination de la composition des tourteaux de quatre variétés de carthame sélectionnées et adaptées dans cette région. La caractérisation des tourteaux étudiés a été effectuée en analysant les protéines, les acides aminés, les fibres, les sucres et les éléments minéraux. Les résultats des analyses effectuées indiquent que la teneur en protéines varie dans une gamme de 17,06-27,05\% de matière sèche, les fibres 63,45-69,97\%, les sucres $12,40-17,07 \%$ et les cendres 3,11-3,60\%. L'acide aminé le plus abondant dans les tourteaux de carthame étudiés est l'acide glutamique $(3,19-3,89 \%$ de matière sèche), tandis que la lysine et la méthionine sont les moins abondantes. La cellulose et l'hémicellulose constituent les fibres les plus représentatives (respectivement, 28,16-31,35\% et 21,04-21,68\% de matière sèche). Le composé majoritaire des sucres est le xylose, dont la teneur varie entre $10,56-14,31 \%$ de matière sèche. Les résultats montrent également que

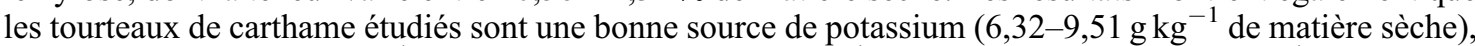
phosphore $\left(2,35-4,60 \mathrm{~g} \mathrm{~kg}^{-1}\right)$, magnésium $\left(2,25-4,25 \mathrm{~g} \mathrm{~kg}^{-1}\right)$ et calcium $\left(1,53-1,72 \mathrm{~g} \mathrm{~kg}^{-1}\right)$. Parmi les

*Corresponding author: f.mansouri@ump.ac.ma 
oligoéléments déterminés, le fer est l'élément majoritaire dans tous les tourteaux analysés (53$\left.125 \mathrm{mg} \mathrm{kg}^{-1}\right)$. En outre, la majorité des paramètres analytiques étudiés ont été fortement influencés par le facteur cultivar $(p<0,05)$. Au vu de ces analyses et la pénurie de pâturages, en particulier pendant les saisons sèches au Maroc oriental, les tourteaux issus de l'extraction de l'huile de grains de carthame peuvent être valorisés par la formulation de nouveaux produits pour l'alimentation animale dans cette région.

Mots clés : carthame / qualité du tourteau / sucres / acides aminés / minéraux

\section{Introduction}

Safflower (Carthamus tinctorius L.) is an oleaginous plant very formerly known worldwide. Also known as false saffron, kardi, kusumb and safflor (Gibbins et al., 2012), safflower belongs to the family of Compositae and is grown in several parts of the world due to its great adaptability to various conditions, including areas with low rainfall (Baümler et al., 2006). Currently, it is grown in nearly 60 countries around the world (FAO, 2017). India, Mexico and the United States are the main producers. The average safflower seeds yield/ha is lower ( 0.72 ton) compared to other oilseeds (Alizadeh et al., 2010), such as soybean (2.34 tons), rapeseed (1.51 tons), peanut (1.37 tons) and sunflower (1.14 tons). However, the seeds of safflower are, compared to 80 oleaginous seeds (Dubois et al., 2007), rich in linoleic acid. Additionally, safflower seeds generally have a white or cream color and contain $26-48 \%$ of oil, $12-22 \%$ of protein and $11-22 \%$ of fiber (Mariod et al., 2012; Aydeniz et al., 2014). The weight of 1000-seed varies between 15-104 $\mathrm{g}$ with a hull percentage that varies between $18-59 \%$ of seed weight (Smith, 1996; Bowles et al., 2010). It has been emphasized in several studies that these characteristics are influenced by genetic variation (Smith, 1996; Amini et al., 2008; Ben Moumen et al., 2015a).

In many parts of the world, safflower seeds are primarily intended for the production of edible oil. The latter is characterized by its high content of linoleic acid and antioxidant compounds (Senkal et al., 2016), its hazelnut flavor and its yellow to golden color (Aydeniz et al., 2014). Safflower oils are extracted by a pressing system, by a solvent extractor or by the use of both methods. Meal is the main byproduct obtained from oil extraction. There are two types of safflower meal obtained from the oil extraction process (Knowles, 1955), indicating a large variation in the composition. One is hulled, and named hulled safflower meal, and the other is dehulled (either totally or partly), and named dehulled safflower meal. Safflower meal is mainly used as an ingredient for animal feed due to its high protein content. In fact, several studies have shown that the incorporation of safflower meal into the feed of ruminants, such as sheep and cattle, improves their performances (Dixon et al., 2003a, b; Dessie et al., 2010). Barbour et al. (2016) showed that the meal of dehulled safflower seeds could replace lysine supplementation in a soybean meal-based feed.

In arid and semi-arid countries, such as Morocco, the high cost of animal feed is recognized as a major problem limiting the production of livestock farmers. Therefore, the use of agricultural by-products, such as safflower meal, as a livestock feed ingredient is a right strategy in low-input systems to improve performances. Even though the chemical composition of safflower grains has been identified by other researchers, the lack of data on the characteristics of safflower plants grown in Morocco led us to undertake this study. Analyses of the composition and quality of safflower oils of Cartafri, Cartamar, Rancho and Sharda varieties have already been carried out in our laboratory (Ben Moumen et al., 2015a, b). They focused mainly on the major and minor compounds of the oils of these four varieties. However, to our knowledge, there are no other studies that include the protein fraction, carbohydrates and minerals of these varieties. The aim of this work is to complete the characterization of the seeds of these four varieties of safflower cultivated in the oriental region of Morocco. Specifically, we are interested in the characterization of the meals of four varieties of safflower (Cartafri, Cartamar, Rancho and Sharda) in terms of dry matter, proteins (total nitrogen, protein fractions and amino acid composition), fibers, carbohydrates and mineral matter (total ash and mineral elements).

\section{Material and methods}

\subsection{Plant material and sample preparation}

The study focuses on the seeds (pure lines) of four varieties of safflower (Carthamus tinctorius L.) from different origins: Cartafri and Cartamar (Morocco), Rancho (Spain) and Sharda (India). Seed cultivation was carried out in February 2010 at the Centre for Agricultural Qualification Bouchtat in Oujda (North East of Morocco; latitude: $34^{\circ} 695 \mathrm{~N}$, longitude: $001^{\circ} 875 \mathrm{~W}$, altitude: $534 \mathrm{~m}$ ). The seeds of these four varieties were kindly provided by the National Institute for Agricultural Research (INRA), Regional Research Centre of Meknes, Morocco.

The safflower seeds of the studied varieties were sorted and cleaned before being grinded with a coffee grinder. Soxlhet system was used for oil extraction using n-hexane at $65^{\circ} \mathrm{C}$ for 5 hours. Then, the meals were recovered, dried and then stored in glass bottles at $4{ }^{\circ} \mathrm{C}$ until analysis.

\subsection{Dry matter}

Meal moisture was determined by drying at $105^{\circ} \mathrm{C}$ according to method 925.09 of the Association of Official Analytical Chemists (AOAC, 2005).

\subsection{Determination of total protein and protein fractions}

Total protein content $(N \times 6.25)$ was evaluated from $100 \mathrm{mg}$ of dried meal using the Kjeldahl Method (AOAC, 2005). 
The protein fractions of the analyzed samples were extracted by the method of Sammour (1999). Three hundred miligrams of dried meal were extracted with $1 \mathrm{ml}$ of distilled water for the albumin fraction, $1 \mathrm{ml}$ of $5 \mathrm{M} \mathrm{NaCl}$ for the globulin fraction, $1 \mathrm{ml}$ of ethanol absolute for the prolamin fraction and $1 \mathrm{ml}$ of $0.2 \mathrm{M}$ phosphate buffer for the glutelin fraction. The concentration of the extracted proteins was determined by the method of Bradford (1976) at $595 \mathrm{~nm}$ on a UV-visible spectrophotometer (RAYLEIGH UV1800) using a calibration curve of bovine serum albumin (Sigma-Aldrich, St. Louis, MO, USA).

\subsection{Amino acids analysis}

Five hundred miligrams of dried safflower meal were dissolved in $10 \mathrm{ml}$ of $6 \mathrm{~N}$ hydrochloric acid containing $0.1 \%$ of phenol. The sample was then hydrolyzed under nitrogen at $110{ }^{\circ} \mathrm{C}$ for 24 hours. After cooling and adjusting $\mathrm{pH}$ to 2.2 using $\mathrm{NaOH}, 0.5 \mathrm{ml}$ of norleucine (Sigma-Aldrich, St. Louis, $\mathrm{MO}, \mathrm{USA})$ at $50 \mu \mathrm{M} \mathrm{ml}^{-1}$ was added as an internal standard. The sample was then filtered through a $0.2 \mu \mathrm{m}$ filter and $20 \mu \mathrm{l}$ of the filtrate were analyzed by high performance liquid chromatography (HPLC Biochrom Plus amino acid analyzer, Pharmacia, Cambridge, UK) equipped with sodium oxidized column, cation exchange resin, followed by post-column derivatisation of the amino acids to ninhydrin and spectrophotometric detection at $570 \mathrm{~nm}$, except for proline, which was detected at $440 \mathrm{~nm}$.

\subsection{Determination of fiber content}

The analysis of the fibers (lignin, cellulose and hemicellulose) was carried in accordance with the methods described by Van Soest $(1963,1967)$. The content of neutral detergent fiber (NDF), acid detergent fiber (ADF) and acid detergent lignin (ADL) was determined using Fibertec 1023 semi-automated dietary fiber analysis system (Foss Analytical AB, Sweden). After carrying out the various extractions, the fiber contents are calculated by the following formulas:

Lignin $=\mathrm{ADL}$

Hemicellulose $=\mathrm{NDF}-\mathrm{ADF}$

Cellulose $=\mathrm{ADF}-\mathrm{ADL}$

\subsection{Determination of total sugars by GC}

Monosaccharides of the sample were liberated by acid hydrolysis and were then determined by gas chromatography (GC) using the alditol acetate method according to the procedure described by Blakeney et al. (1983). Twenty miligrams of dried meal were hydrolyzed with $3 \mathrm{ml}$ of $\mathrm{H}_{2} \mathrm{SO}_{4}$ for 3 hours at $100{ }^{\circ} \mathrm{C}$. Sugar content was determined using a Hewlett-Packard HP6890 GC (Agilent, Palo Alto, CA, USA) equipped with a flame ionization detector and an HP1methylsiloxane capillary column $(30 \mathrm{~cm} \times 320 \mu \mathrm{m}, 0.25 \mu \mathrm{m}$; SGE Pty. Ltd., Melbourne, Australia). The used carrier gas is helium (99.999\%, Air Liquide, Liège, Belgium). Solutions of 2-deoxyglucose (internal standard), arabinose, glucose, galactose, mannose and xylose (Sigma-Aldrich, St. Louis, MO, USA) were used as standards for the identification and quantification of the various components.

\subsection{Determination of ash content and mineral elements}

The ash percentage was quantified by incineration at $600{ }^{\circ} \mathrm{C}$ for 6 hours according to the official method 923.03 of the Association of Official Analytical Chemists (AOAC, 2005).

The concentrations of calcium, copper, iron, magnesium, manganese, phosphorus and zinc were measured after mineralization by atomic absorption spectrometry (Perkin Elmer 1100B Atomic Absorption, Norwalk, CT, USA). One gram of dried safflower meal is weighed into a teflon container with $6 \mathrm{ml}$ of $65 \%$ nitric acid and $1 \mathrm{ml}$ of $35 \%$ hydrogen peroxide. The mineralization was carried out in a highperformance microwave digestion unit (MLS $1200 \mathrm{meg}$ ) using the following program: $250 \mathrm{~W}: 2 \mathrm{~min} ; 0 \mathrm{~W}: 2 \mathrm{~min} ; 250 \mathrm{~W}$ : $6 \mathrm{~min}$; $400 \mathrm{~W}$ : $5 \mathrm{~min}$; $600 \mathrm{~W}$ : $5 \mathrm{~min}$; ventilation: $10 \mathrm{~min}$. Potassium concentration was determined using a flameemitting photometer (Eppendorf, Hamburg, Germany). Total phosphorus in safflower meal was measured after mineralization of the samples by the molybdenum blue method (Scheel, 1936) at $700 \mathrm{~nm}$ using a Shimadzu UV-1205 spectrophotometer (Shimadzu, Kyoto, Japan).

\subsection{Statistical analysis}

The results presented in this work are the means of the analyses carried out in triplicate with the corresponding standard deviations (for each parameter: 3 determinations $\times 3$ samples $=9$ ). The ANOVA One-Way statistical analysis and the Duncan post hoc test were used to find the significant differences between the means. The significant difference threshold was set at 5\%. Results were also assessed by Principal Component Analysis (PCA) and Hierarchical Cluster Analysis (HCA). The applications of these statistical analyses were carried out using software for Windows: XLSTAT, version 16.5.03 (Addinsoft, 2014) and IBM Statistical Package for Social Sciences (IBM SPSS. 20).

\section{Results and discussion}

\subsection{Moisture and dry matter content}

The results obtained from the meal samples of the four studied safflower varieties show that there are significant differences between the studied varieties $(p<0.05)$ in the dry matter content (Tab. 1). They ranged between $98.58 \%$ for the Rancho variety and $97.65 \%$ for the Cartafri variety. A change in the dry matter implies the variation of the water content. For the four varieties, the average water content is $1.42 \%$ for the Rancho variety, $1.56 \%$ for the Sharda variety, $1.61 \%$ for the Cartamar variety and $2.35 \%$ for the Cartafri variety. The obtained values are lower than those of safflower meal reported by Galicia-González et al. (2010) and Farran et al. (2010). These results show that the meals obtained from the seeds of the four studied varieties of safflower are favorable for long-term storage. From a microbiological standpoint, low water levels limit the development of microorganisms, with the exception of molds (Chapeland-Leclerc et al., 2005). 
Table 1. Proximal composition of Rancho, Cartamar, Cartafri and Sharda safflower meals.

\begin{tabular}{llll}
\hline & \multicolumn{2}{c}{ Varieties } \\
\cline { 2 - 4 } Parameters & Rancho & Cartamar & Cartafri \\
\hline Moisture (\%) & $1.42 \pm 0.01^{\mathrm{a}}$ & $1.61 \pm 0.12^{\mathrm{b}}$ & $2.35 \pm 0.04^{\mathrm{c}}$ \\
Dry matter (\%) & $98.58 \pm 0.01^{\mathrm{c}}$ & $98.39 \pm 0.12^{\mathrm{b}}$ & $97.65 \pm 0.04^{\mathrm{a}}$ \\
Ash (\% of dry matter) & $3.60 \pm 0.04^{\mathrm{b}}$ & $3.41 \pm 0.03^{\mathrm{c}}$ & $3.58 \pm 0.05^{\mathrm{c}}$ \\
Crude protein (\% of dry matter) & $27.05 \pm 0.10^{\mathrm{d}}$ & $17.06 \pm 0.08^{\mathrm{a}}$ & $22.56 \pm 0.56^{\mathrm{c}}$ \\
\hline
\end{tabular}

Values are the means of the four different safflower meal samples $(n=9) \pm$ standard deviations. Significant differences $(p<0.05)$ in the same line are indicated by different letters $(\mathrm{a}-\mathrm{d})$.

\subsection{Total proteins and protein fractions}

Protein intake is very important for growing or breeding animals. The latter need a high-protein diet for mass gain. The protein content of meals is a very important index in livestock feed. Its nutritional value takes into account the amino acid composition and determines its economic importance. The protein content varies significantly $(p<0.05)$ between the analyzed samples (Tab. 1). Rancho meal has the highest content (27.05\% of dry matter), followed by Cartafri (22.56\%), Sharda $(18.70 \%)$ and Cartamar $(17.07 \%)$. The protein levels observed in the Rancho and Cartafri varieties are higher than those reported by Galicia-González et al. (2010) in the meals of dehulled safflower seeds (20.65\%). However, the meals of the Sharda and Cartamar varieties have lower levels than those reported by the same study.

As far as protein fractions are concerned, knowledge of protein isolates from plant sources is of interest because of their functional properties which can improve the nutritional quality in human or animal nutrition. The results of the analysis of the protein fractions are summarized in Table 2. Globulin is the most abundant fraction in the analyzed safflower meals constituting $42-50 \%$ of the analyzed fractions, followed by albumin (26-32\%), glutelin (21-26\%) and prolamin (1-3\%). Table 2 shows that the highest levels of globulin, albumin and glutelin were found in the Rancho variety $(2.25,1.16$ and $0.93 \%$ of dry matter), and the highest value of prolamin was found in the Sharda meal $(0.09 \%)$. These results are in accordance with the values reported by Movahhedy-Dehnavy et al. (2009) for globulin (15.7-36.3 $\mathrm{mg} \mathrm{g}^{-1}$ seed flour), while the albumin, glutenin and prolamin values in the analyzed safflower meals are lower than those reported by the same authors for other varieties of safflower.

\subsection{Amino acid composition}

The estimation of protein requirements takes into account not only their quantity but also their quality. This is mainly determined by the amino acid composition, essential amino acids in particular. The amino acid determination of the analyzed samples (Tab. 3) shows a clear influence of the varietal factor on the total amino acid content $(p<0.05)$. Total amino acid rates range from 15.56 (Rancho) to $20.01 \%$ of dry matter (Cartafri). The results of the Rancho variety are comparable to those reported by Angelova et al. (2014), which determined $15.61 \%$ of amino acids in safflower meals, while the values obtained in other varieties are higher than those reported by the same authors.
Table 2. Protein fractions of Rancho, Cartamar, Cartafri and Sharda safflower meals.

\begin{tabular}{lllll}
\hline & \multicolumn{4}{c}{ Varieties } \\
\cline { 2 - 5 } $\begin{array}{l}\text { Protein fractions } \\
\text { (\% of dry matter) }\end{array}$ & Rancho & Cartamar & Cartafri & Sharda \\
\hline Albumen & $1.16 \pm 0.00^{\mathrm{b}}$ & $1.14 \pm 0.06^{\mathrm{b}}$ & $1.08 \pm 0.05^{\mathrm{a}}$ & $1.06 \pm 0.02^{\mathrm{a}}$ \\
Globulin & $2.25 \pm 0.09^{\mathrm{c}}$ & $1.70 \pm 0.07^{\mathrm{b}}$ & $1.47 \pm 0.06^{\mathrm{a}}$ & $1.43 \pm 0.23^{\mathrm{a}}$ \\
Prolamin & $0.08 \pm 0.00^{\mathrm{b}}$ & $0.07 \pm 0.01^{\mathrm{a}}$ & $0.07 \pm 0.00^{\mathrm{a}}$ & $0.09 \pm 0.01^{\mathrm{b}}$ \\
Glutelin & $0.93 \pm 0.05^{\mathrm{c}}$ & $0.88 \pm 0.01^{\mathrm{b}}$ & $0.87 \pm 0.03^{\mathrm{b}}$ & $0.81 \pm 0.04^{\mathrm{a}}$ \\
\hline
\end{tabular}

Values are the means of the four different safflower meal samples $(n=9) \pm$ standard deviations. Significant differences $(p<0.05)$ in the same line are indicated by different letters $(a-d)$.

Table 3. Amino acid composition of Rancho, Cartamar, Cartafri and Sharda safflower meals.

\begin{tabular}{lllll}
\hline & \multicolumn{4}{c}{ Varieties } \\
\cline { 2 - 5 } $\begin{array}{l}\text { Amino acids } \\
\text { (\% of dry }\end{array}$ & Rancho & Cartamar & Cartafri & Sharda \\
matter) & & & & \\
\hline & & & & \\
Aspartic acid & $1.73 \pm 0.08^{\mathrm{a}}$ & $1.85 \pm 0.11^{\mathrm{b}}$ & $2.10 \pm 0.05^{\mathrm{c}}$ & $1.91 \pm 0.05^{\mathrm{b}}$ \\
Threonine & $0.62 \pm 0.04^{\mathrm{a}}$ & $0.68 \pm 0.04^{\mathrm{b}}$ & $0.82 \pm 0.02^{\mathrm{d}}$ & $0.72 \pm 0.02^{\mathrm{c}}$ \\
Serine & $0.85 \pm 0.04^{\mathrm{a}}$ & $0.93 \pm 0.05^{\mathrm{b}}$ & $1.10 \pm 0.03^{\mathrm{d}}$ & $0.99 \pm 0.03^{\mathrm{c}}$ \\
Glutamic acid & $3.19 \pm 0.12^{\mathrm{a}}$ & $3.38 \pm 0.24^{\mathrm{b}}$ & $3.89 \pm 0.07^{\mathrm{d}}$ & $3.53 \pm 0.09^{\mathrm{c}}$ \\
Proline & $0.66 \pm 0.02^{\mathrm{a}}$ & $0.64 \pm 0.03^{\mathrm{a}}$ & $0.83 \pm 0.05^{\mathrm{b}}$ & $0.71 \pm 0.05^{\mathrm{b}}$ \\
Glycine & $0.93 \pm 0.03^{\mathrm{a}}$ & $0.99 \pm 0.05^{\mathrm{b}}$ & $1.17 \pm 0.02^{\mathrm{d}}$ & $1.05 \pm 0.03^{\mathrm{c}}$ \\
Alanine & $0.70 \pm 0.03^{\mathrm{a}}$ & $0.75 \pm 0.04^{\mathrm{b}}$ & $0.93 \pm 0.01^{\mathrm{d}}$ & $0.83 \pm 0.03^{\mathrm{c}}$ \\
Valine & $0.99 \pm 0.04^{\mathrm{a}}$ & $1.05 \pm 0.05^{\mathrm{b}}$ & $1.25 \pm 0.03^{\mathrm{d}}$ & $1.11 \pm 0.05^{\mathrm{c}}$ \\
Methionine & $0.16 \pm 0.01^{\mathrm{a}}$ & $0.20 \pm 0.02^{\mathrm{b}}$ & $0.30 \pm 0.01^{\mathrm{d}}$ & $0.25 \pm 0.01^{\mathrm{c}}$ \\
Isoleucine & $0.66 \pm 0.03^{\mathrm{a}}$ & $0.70 \pm 0.05^{\mathrm{b}}$ & $0.85 \pm 0.04^{\mathrm{d}}$ & $0.76 \pm 0.04^{\mathrm{c}}$ \\
Leucine & $1.13 \pm 0.05^{\mathrm{a}}$ & $1.22 \pm 0.05^{\mathrm{b}}$ & $1.47 \pm 0.03^{\mathrm{d}}$ & $1.31 \pm 0.06^{\mathrm{c}}$ \\
Tyrosine & $0.39 \pm 0.01^{\mathrm{a}}$ & $0.46 \pm 0.03^{\mathrm{b}}$ & $0.61 \pm 0.02^{\mathrm{d}}$ & $0.49 \pm 0.03^{\mathrm{c}}$ \\
Phenylalanine & $0.77 \pm 0.04^{\mathrm{a}}$ & $0.85 \pm 0.09^{\mathrm{b}}$ & $1.04 \pm 0.05^{\mathrm{d}}$ & $0.94 \pm 0.06^{\mathrm{c}}$ \\
Histidine & $0.62 \pm 0.04^{\mathrm{a}}$ & $0.67 \pm 0.05^{\mathrm{b}}$ & $0.80 \pm 0.03^{\mathrm{d}}$ & $0.71 \pm 0.03^{\mathrm{c}}$ \\
Lysine & $0.63 \pm 0.06^{\mathrm{a}}$ & $0.73 \pm 0.06^{\mathrm{b}}$ & $0.84 \pm 0.03^{\mathrm{c}}$ & $0.80 \pm 0.04^{\mathrm{c}}$ \\
Arginine & $1.53 \pm 0.08^{\mathrm{a}}$ & $1.63 \pm 0.09^{\mathrm{b}}$ & $2.01 \pm 0.05^{\mathrm{d}}$ & $1.74 \pm 0.08^{\mathrm{c}}$ \\
Total amino & $15.56 \pm 0.61^{\mathrm{a}}$ & $16.71 \pm 0.66^{\mathrm{b}}$ & $20.01 \pm 0.40^{\mathrm{d}}$ & $17.86 \pm 0.56^{\mathrm{c}}$ \\
acids & & & & \\
\hline
\end{tabular}

Values are the means of the four different safflower meal samples $(n=9) \pm$ standard deviations. Significant differences $(p<0.05)$ in the same line are indicated by different letters $(a-d)$. 
Separation and identification of amino acids by HPLC show the presence of 16 amino acids in the analyzed samples, including seven essential amino acids (histidine, isoleucine, leucine, lysine, methionine, phenylalanine and valine). Statistical analysis showed significant differences between the studied varieties $(p<0.05)$ for all the identified amino acids. Table 3 shows that the highest levels of identified amino acids were recorded in the Cartafri meal, while the Rancho variety showed the lowest values. Glutamic acid is the main amino acid, its content varies between 3.89 and $3.19 \%$ of dry matter, followed by aspartic acid (1.73-2.10\%), arginine $(1.53-2.01 \%)$, leucine $(1.22-1.47 \%)$ and glycine $(0.93-$ $1.17 \%$ ). The high levels of glutamic and aspartic acids could be due to the experimental conditions that could cause the transformation of glutamine and asparagine into glutamic and aspartic acids, respectively. However, hydrolysis under nitrogen with very pure hydrochloric acid decreases oxidations. It should be noted that basic hydrolysis was not performed to determine the presence and quantification of tryptophan. These results are comparable with those published by Galicia-González et al. (2010), who found that glutamic acid, aspartic acid, arginine, leucine and glycine are the main amino acids for other safflower meals. However, the concentrations of the identified amino acids in the analyzed samples, particularly for the Cartamar, Cartafri and Sharda varieties, are different from those reported in the same study. The contents of histidine, lysine, methionine, phenylalanine and serine were higher, while the aspartic acid, alanine, glutamic acid, glycine, valine and isoleucine contents were lower. The amounts of leucine, threonine and tyrosine were comparable. Nosheen et al. (2016) showed that the variation in amino acid content was not only genetic (varietal) but also dependent on growing conditions (including fertilization). Lysine and methionine are the most important essential amino acids for animal feed. Safflower meals of the studied varieties showed low levels of these two amino acids compared to soybean meal (Farran et al., 2010). Their levels ranged from 0.63 to $0.84 \%$ of dry matter for lysine and from 0.16 to $0.30 \%$ for methionine (Tab. 3).

\subsection{Fiber content and composition}

The fiber fraction is an important element in the diet of animals. At some level, fibers improve intestinal movement for a healthy digestive system. However, high levels of fiber in the diet may cut its nutritional value, resulting in a delay in growth and reproductive performance (Hinton, 2007). In this study, we analyzed three types of fiber: cellulose, hemicellulose and lignin. The results of the analyses are presented in Table 4. Cellulose content varies between 28.16 (Rancho) and 31.35\% of dry matter (Cartamar), while hemicellulose content varies between 21.04 (Rancho) and 21.68\% (Sharda) and lignin content varies between 13.13 (Cartafri) and $17.40 \%$ (Cartamar). The highest percentage of total fibers was observed in Cartamar $(69.97 \%$ of dry matter), while the lowest was observed in Cartafri $(63.45 \%)$. The observed variations between the studied varieties in the different fractions of the fibers are statistically significant $(p<0.05)$. This observed fiber richness in the four studied varieties is mainly due to the use of hulled seeds in our study. Safflower seed is characterized
Table 4. Fibers composition of Rancho, Cartamar, Cartafri and Sharda safflower meals.

\begin{tabular}{lllll}
\hline & \multicolumn{4}{c}{ Varieties } \\
\cline { 2 - 5 } $\begin{array}{l}\text { Fibers } \\
\text { (\% of dry } \\
\text { matter) }\end{array}$ & Rancho & Cartamar & Cartafri & Sharda \\
\hline $\begin{array}{l}\text { Cellulose } \\
\text { Hemi }\end{array}$ & $28.16 \pm 0.28^{\mathrm{a}}$ & $31.35 \pm 1.29^{\mathrm{c}}$ & $28.91 \pm 0.05^{\mathrm{b}}$ & $29.06 \pm 0.50^{\mathrm{b}}$ \\
cellulose & $21.04 \pm 0.10^{\mathrm{a}}$ & $21.22 \pm 0.64 \mathrm{a}^{\mathrm{b}}$ & $21.41 \pm 0.09 \mathrm{~b}^{\mathrm{c}}$ & $21.68 \pm 0.13^{\mathrm{c}}$ \\
$\begin{array}{l}\text { Lignin } \\
\text { Total fibers }\end{array}$ & $65.48 \pm 0.69^{\mathrm{b}}$ & $69.97 \pm 1.24^{\mathrm{c}}$ & $63.45 \pm 0.20^{\mathrm{a}}$ & $65.22 \pm 0.51^{\mathrm{b}}$ \\
\hline
\end{tabular}

Values are the means of the four different safflower meal samples $(n=9) \pm$ standard deviations. Significant differences $(p<0.05)$ in the same line are indicated by different letters $(a-d)$.

by a very important hull which increases its fiber content. This limits the use of safflower meal of hulled seeds to high percentages in the formulation of livestock and poultry feeds, particularly for the monogastrics. Therefore, partial or total dehulling would be desirable for proper use of safflower meal. In fact, Farran et al. (2010) showed that dehulling reduces the fiber content by $35 \%$ in the meal of hulled safflower seeds to $13 \%$ in the meal from partly dehulled seeds. While complete removal of hulls prior to oil extraction further reduced fiber content to less than $3 \%$, making safflower meal more suitable for incorporation into poultry feed.

\subsection{Total sugars content}

Energy is obtained from carbohydrates, such as simple sugars, starch and fibers. These feed components provide energy for animals to maintain body heat and to perform normal body functions and activities (Hinton, 2007). The total sugar content (Tab. 5), expressed as a percentage of dry matter, varies significantly $(p<0.05)$ between $12.40 \%$ (Cartamar) and $17.07 \%$ (Sharda). The major compound of the total sugars after hydrolysis is xylose, which is a pentose, whose content varies between 10.56 (Cartafri) and $14.31 \%$ of dry matter (Sharda), followed by rhamnose and mannose with levels varying, respectively between $0.51 \%$ and $0.54 \%$ in the Rancho variety and 0.72 and $1.14 \%$ in the Sharda variety. Glucose levels ranged between $0.36 \%$ (Rancho) and $0.52 \%$ (Sharda) and arabinose and galactose varied between $0.13 \%$ and $0.11 \%$ (Cartamar) and 0.21 and $1.18 \%$ (Sharda), respectively. These observed variations between the meals of the studied varieties are statistically significant $(p<0.05)$. Analyses results of total sugars are comparable to those reported by Nagaraj (1995).

\subsection{Mineral content and composition}

The ash content represents the mineral part of a meal and allows to have an idea on its mineral salts input. Statistical analysis (ANOVA) of the total ash content revealed significant differences $(p<0.05)$ between the meals of the different studied varieties of safflower. Total ash content ranged between $3.11 \%$ of dry matter for the Sharda variety and $3.60 \%$ for the Rancho variety (Tab. 1). These values are higher 
Table 5. Carbohydrates composition of Rancho, Cartamar, Cartafri and Sharda safflower meals.

\begin{tabular}{lllll}
\hline & \multicolumn{4}{c}{ Varieties } \\
\cline { 2 - 5 } $\begin{array}{l}\text { Carbohydrates } \\
\text { (\% of dry }\end{array}$ & Rancho & Cartamar & Cartafri & Sharda \\
matter) & & & & \\
\hline Rhamnose & $0.51 \pm 0.05^{\mathrm{a}}$ & $0.53 \pm 0.18^{\mathrm{a}}$ & $0.69 \pm 0.11^{\mathrm{b}}$ & $0.72 \pm 0.05^{\mathrm{b}}$ \\
Arabinose & $0.19 \pm 0.02^{\mathrm{c}}$ & $0.13 \pm 0.03^{\mathrm{a}}$ & $0.17 \pm 0.03^{\mathrm{a}}$ & $0.21 \pm 0.02^{\mathrm{c}}$ \\
Xylose & $11.39 \pm 1.29^{\mathrm{a}}$ & $10.56 \pm 2.87^{\mathrm{a}}$ & $11.93 \pm 2.54^{\mathrm{a}}$ & $14.31 \pm 1.75^{\mathrm{b}}$ \\
Mannose & $0.54 \pm 0.08^{\mathrm{a}}$ & $0.70 \pm 0.19^{\mathrm{b}}$ & $0.95 \pm 0.14^{\mathrm{c}}$ & $1.14 \pm 0.17^{\mathrm{d}}$ \\
Glucose & $0.36 \pm 0.04^{\mathrm{a}}$ & $0.37 \pm 0.10^{\mathrm{a}}$ & $0.48 \pm 0.07^{\mathrm{b}}$ & $0.52 \pm 0.04^{\mathrm{b}}$ \\
Galactose & $0.13 \pm 0.01^{\mathrm{b}}$ & $0.11 \pm 0.03^{\mathrm{a}}$ & $0.11 \pm 0.01^{\mathrm{a}}$ & $0.18 \pm 0.01^{\mathrm{c}}$ \\
Total & $13.13 \pm 1.43^{\mathrm{a}}$ & $12.40 \pm 3.17^{\mathrm{a}}$ & $14.33 \pm 2.80^{\mathrm{a}}$ & $17.07 \pm 1.81^{\mathrm{b}}$ \\
carbohydrates & & & & \\
\hline
\end{tabular}

Values are the means of the four different safflower meal samples $(n=9) \pm$ standard deviations. Significant differences $(p<0.05)$ in the same line are indicated by different letters $(a-d)$.

Table 6. Content of micro and macroelements in Rancho, Cartamar, Cartafri and Sharda safflower meals.

\begin{tabular}{lllll}
\hline & \multicolumn{4}{c}{ Varieties } \\
\cline { 2 - 5 } Minerals & Rancho & Cartamar & Cartafri & Sharda \\
\hline Macroelements & & & & \\
$\left(\mathrm{g} \mathrm{kg}^{-1}\right)$ & & & & \\
Potassium $_{\text {Magnesium }}$ & $6.62 \pm 0.02^{\mathrm{b}}$ & $6.32 \pm 0.07^{\mathrm{a}}$ & $9.51 \pm 0.02^{\mathrm{d}}$ & $6.79 \pm 0.01^{\mathrm{c}}$ \\
Calcium & $1.69 \pm 0.01^{\mathrm{b}}$ & $2.25 \pm 0.01^{\mathrm{a}}$ & $4.25 \pm 0.04^{\mathrm{d}}$ & $3.37 \pm 0.02^{\mathrm{c}}$ \\
Phosphor & $2.92 \pm 0.00^{\mathrm{b}}$ & $2.35 \pm 0.01^{\mathrm{d}}$ & $1.53 \pm 0.00^{\mathrm{a}}$ & $1.56 \pm 0.01^{\mathrm{b}}$ \\
Microelements & & $4.60 \pm 0.00^{\mathrm{d}}$ & $3.24 \pm 0.00^{\mathrm{c}}$ \\
$\left(\begin{array}{llll}\text { (mg kg } \\
\text { Zinc }\end{array}\right.$ & & & & \\
Zinc & $40.48 \pm 0.12^{\mathrm{b}}$ & $37.62 \pm 0.09^{\mathrm{a}}$ & $85.37 \pm 2.65^{\mathrm{d}}$ & $56.95 \pm 0.35^{\mathrm{c}}$ \\
Copper & $11.86 \pm 0.27^{\mathrm{a}}$ & $15.85 \pm 0.36^{\mathrm{b}}$ & $21.62 \pm 0.24^{\mathrm{c}}$ & $15.70 \pm 0.37^{\mathrm{b}}$ \\
Manganese & $19.23 \pm 0.10^{\mathrm{c}}$ & $16.57 \pm 0.16^{\mathrm{a}}$ & $25.99 \pm 0.44^{\mathrm{d}}$ & $18.28 \pm 0.30^{\mathrm{b}}$ \\
Iron & $124.03 \pm 0.28^{\mathrm{d}}$ & $53.51 \pm 1.10^{\mathrm{a}}$ & $103.07 \pm 0.65^{\mathrm{c}}$ & $78.14 \pm 0.34^{\mathrm{b}}$ \\
\hline
\end{tabular}

Values are the means of the four different safflower meal samples $(n=9) \pm$ standard deviations. Significant differences $(p<0.05)$ in the same line are indicated by different letters $(a-d)$.

than those reported in other studies for other varieties of safflower with ash contents varying between 2.4 and $2.6 \%$ of dry matter (Farran et al., 2010; Aydeniz et al., 2014). Meals of other varieties of safflower (Garg et al., 2012; GaliciaGonzález et al., 2010; Ustaoglu Tiril and Kerim, 2015) show higher values (3.7-6.6\% of dry matter) than those found in our case for the four varieties.

In order to complete the study of mineral matter, we sought to find the mineral content. We have only analyzed the four major elements (potassium, magnesium, calcium, phosphorus) as well as the main microelements (zinc, copper, manganese and iron). Table 6 shows that the contents of the determined mineral elements vary according to the considered variety $(p<0.05)$. The results also show that the studied safflower meals are a good source of major elements. Potassium represents the major element in the analyzed samples with a content ranging from 6.26 to $9.51 \mathrm{~g} \mathrm{~kg}^{-1}$ of dry matter, followed by phosphorus $\left(2.23-4.60 \mathrm{~g} \mathrm{~kg}^{-1}\right)$, magnesium $\left(2.25-4.25 \mathrm{~g} \mathrm{~kg}^{-1}\right)$ and calcium $\left(1.53-1.72 \mathrm{~g} \mathrm{~kg}^{-1}\right)$. The highest concentrations were observed in the Cartafri variety for potassium, magnesium and phosphorus, and the Cartamar variety for calcium. Phosphorus, potassium and calcium values observed in our study are lower than those reported by Gowda et al. (2004) and Angelova et al. (2014), while magnesium contents are comparable to those observed by the same authors.

Among the determined microelements, iron is the major element of this fraction in all the analyzed safflower meals (53$125 \mathrm{mg} \mathrm{kg}^{-1}$ of dry matter), followed by zinc, manganese and copper, whose contents are $37-85,16-26$ and $11-22 \mathrm{mg} \mathrm{kg}^{-1}$, respectively. These values are lower than those mentioned by Gowda et al. (2004), who reported $422 \mathrm{ppm}$ for iron, $90 \mathrm{ppm}$ for zinc and $24 \mathrm{pm}$ for copper. According to Table 6, the highest iron content was found in the Rancho variety $\left(124.04 \mathrm{mg} \mathrm{kg}^{-1}\right)$, while the lowest was found in the Cartamar variety $\left(53.51 \mathrm{mg} \mathrm{kg}^{-1}\right)$. Cartafri meal has the highest levels of zinc $\left(85.37 \mathrm{mg} \mathrm{kg}^{-1}\right)$, manganese $\left(25.99 \mathrm{mg} \mathrm{kg}^{-1}\right)$ and copper $\left(21.62 \mathrm{mg} \mathrm{kg}^{-1}\right)$, while the lowest values were respectively observed in the Cartamar (37.62 and $\left.16.57 \mathrm{mg} \mathrm{kg}^{-1}\right)$ and Rancho $\left(11.86 \mathrm{mg} \mathrm{kg}^{-1}\right)$ varieties.

\subsection{Multivariate analysis}

The variation in the composition of the safflower meals of the four studied varieties led us to perform a PCA. It is a multivariate technique that reduces the number of variables into a few factors with most variations. The analysis is generally used for classification. The PCA results allowed us to isolate thirty-one Factors (F) explaining $100 \%$ of the analyzed variances, the first two of which accounted for $72.11 \%$ of total information with eigenvalues of 24.84 for F1 and 6.16 for F2. The representation of the analyzed safflower meals on the main plane (F1 and F2) as well as the circle of correlations of the associated variables are presented in Figures 1 and 2. The most contributing parameters of F1 are mainly amino acids and minerals (potassium, magnesium, phosphorus, manganese, zinc and copper). These parameters showed positive correlations with F1. Projection of the cultivars on the factorial map allows a clear separation between the analyzed samples. It's interesting to note that the Cartafri variety meal has a distant profile from other varieties. Compared to F1, the Cartafri variety meal is completely opposite to the Rancho and Cartamar varieties, as it is more correlated to this factor than the Sharda variety. This means that Cartamar is very different compared to other varieties, since the first axis is the one that better separates the points, as it explains $57.78 \%$ of the information.

The PCA results were confirmed by the HCA test. The dendrogram obtained from this analysis shows that at a distance of 254.37 the cultivars are divided into three groups (Fig. 3). Cluster 1 is formed by the Sharda variety, which is distinguished from other varieties by its high carbohydrate proportion and intermediate values of amino acids and minerals. The Cartafri variety, which characterized by high levels of amino acids and minerals, forms Cluster 2. Finally, Cluster 3 includes the Rancho and Cartamar varieties. 


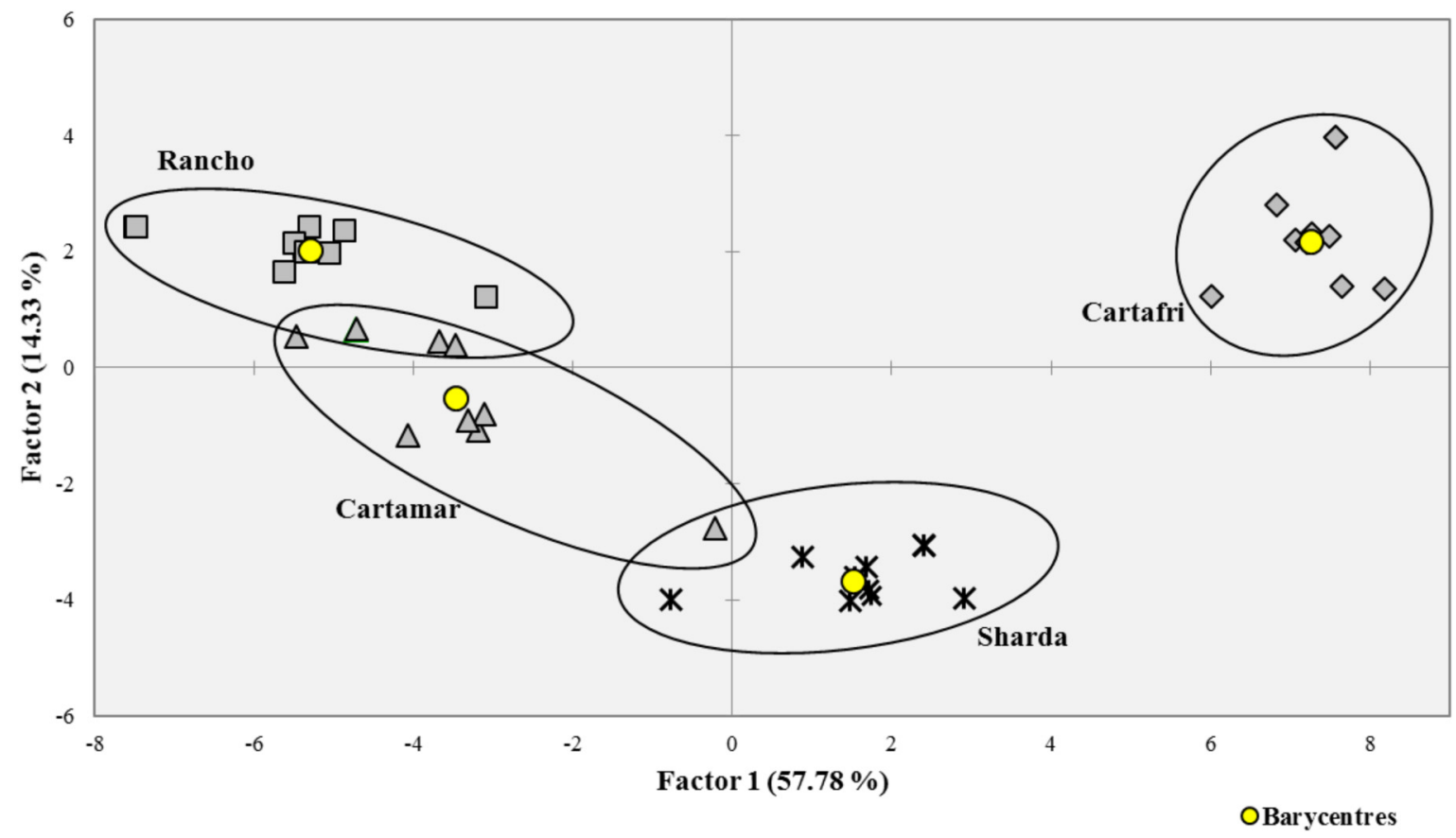

Fig. 1. Two dimensional PCA plot of the studied safflower varieties (Rancho, Cartamar, Cartafri and Sharda) using the whole data set of analytical meal variables obtained.

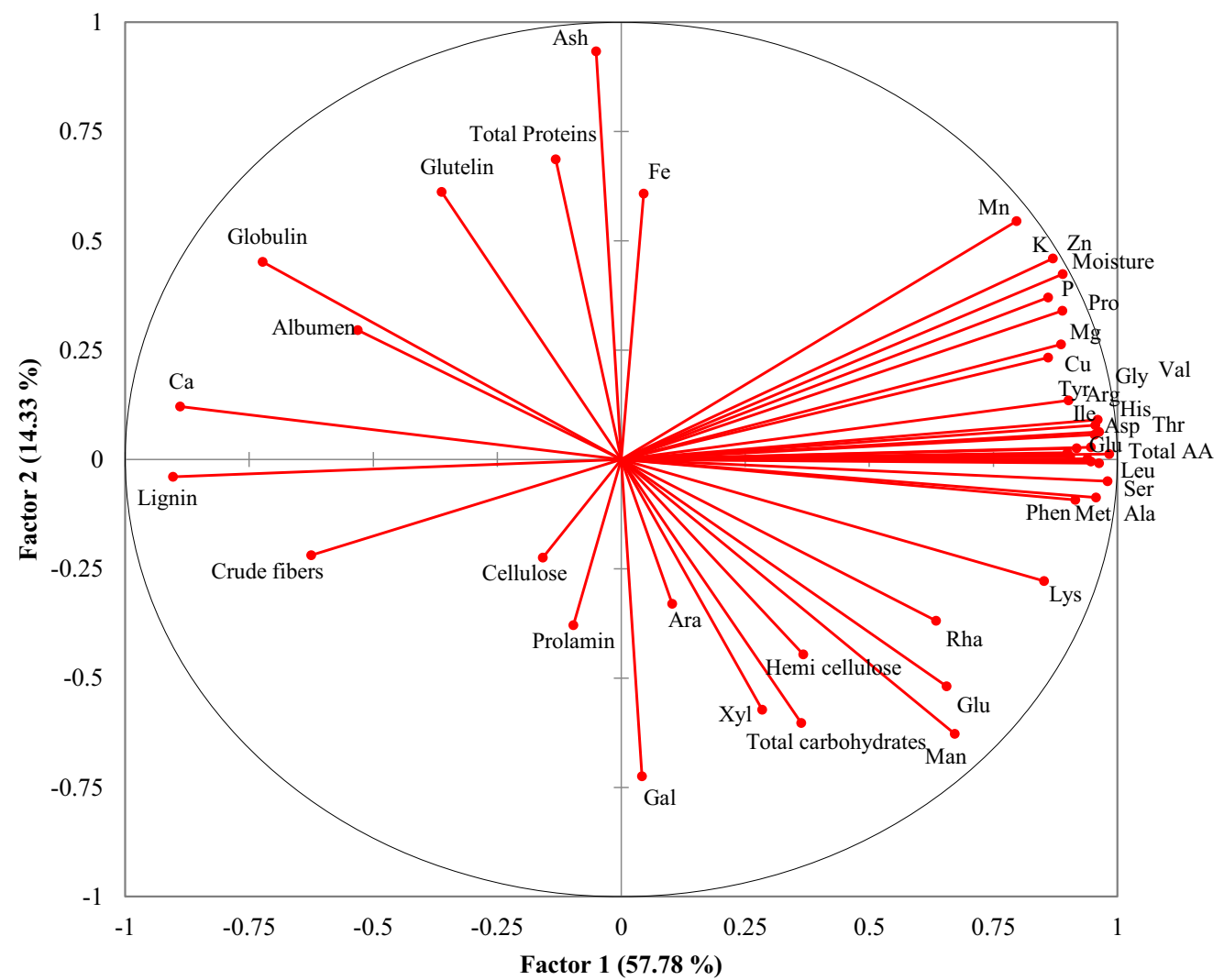

Fig. 2. Loading plot on the plane identified by dimension 1 and 2 obtained from PCA applied to the data set of analytical meal variables from different studied safflower varieties. 


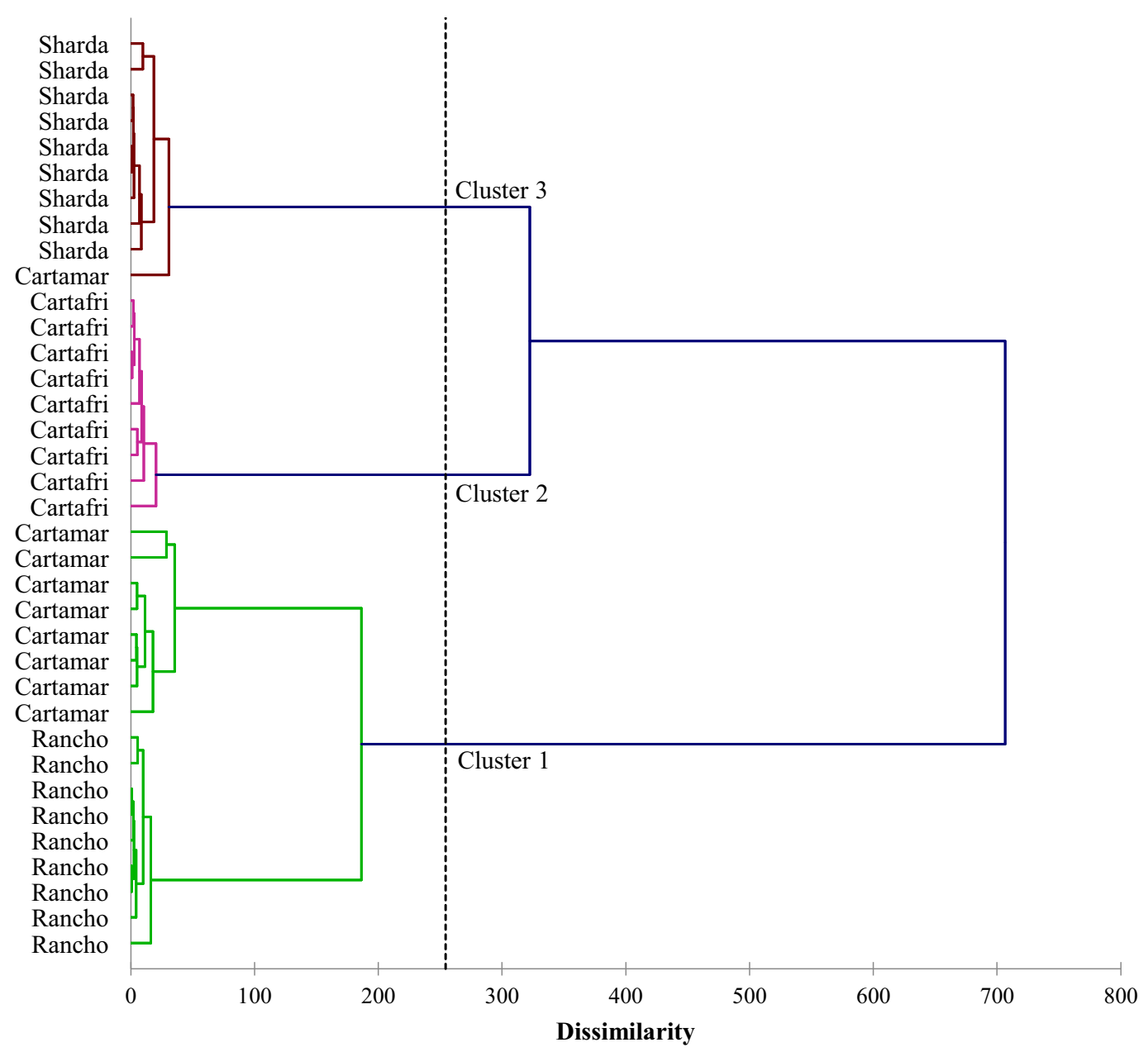

Fig. 3. Hierarchical cluster analysis dendrogram of all collected data obtained from safflower meals of the studied varieties (Rancho, Cartamar, Cartafri and Sharda) using Euclidean distance.

\section{Conclusion}

The work carried out in this study is the logical continuation of our work on safflower for its insertion and its valorization as an oleaginous plant adapted to the semi-arid climatic conditions of the oriental region of Morocco. Thus, after studying its resistance to climatic conditions (Zraibi et al., 2011, 2014) and the characterization of its oil (Ben Moumen et al., 2015a, b), we were interested in its meal. The purpose of this work was to characterize this co-product to valorize it for variable uses, particularly for feeding livestock and poultry. The results show that the fiber content is very high because the used meals are derived from hulled seeds. The average protein content is about 17 to $27 \%$. The analysis of amino acid composition reveals that although there is a high protein content, the methionine/lysine ratio remains low for the studied varieties of safflower, which limits its use in large quantities. To optimize the use of safflower meal and create new investment niches for the development of Morocco, it is necessary to use an adequate method of dehulling in order to lower the seeds' fiber content and to reduce the deficit of certain amino acids by mixtures with other meals or by the addition of the deficient amino acids.
Acknowledgements. This study was supported by the Moroccan-Belgian cooperation program "the Wallonia Brussels International project 2.9, 2012-2014". We would like to thank Mr. Abdelouadoud Omari for the time spent in reviewing this paper.

\section{References}

Alizadeh A, Ghorbani G, Alikhani M, Rahmani H, Nikkhah A. 2010. Safflower seeds in corn silage and alfalfa hay based early lactation diets: A practice within an optimum forage choice. Anim Feed Sci Tech 155: 18-24.

Amini F, Saeidi G, Arzani A. 2008. Study of genetic diversity in safflower genotypes using agro-morphological traits and RAPD markers. Euphytica 163: 21-30.

Angelova V, Akova V, Ivanov K. 2014. The effect of organic amendments on the chemical composition of safflower (Carthamus tinctorius L.) meal. J Int Sci Publ: Ecol Saf 8: 441-453.

AOAC. 2005. Official methods of analysis of AOAC International, 18th edn. Gaithersburg, Maryland, AOAC.

Aydeniz B, Güneser O, Yilmaz E. 2014. Physico-chemical, sensory and aromatic properties of cold press produced safflower oil. $\mathrm{J} \mathrm{Am}$ Oil Chem Soc 91: 99-110. 
Barbour G, Usayran N, Yau S, et al. 2016. The effect of safflower meal substitution in a lysine fortified corn-soybean meal diet on performance, egg quality, and yolk fat profile of laying hens. J Appl Poult Res 25: 256-265.

Baümler E, Cuniberti A, Nolasco SM, Riccobene IC. 2006. Moisture dependent physical and compression properties of safflower seed. J Food Eng 72: 134-140.

Ben Moumen A, Mansouri F, Richard G, et al. 2015a. Biochemical characterisation of the seed oils of four safflower (Carthamus tinctorius) varieties grown in north-eastern of Morocco. Inter Food Sci Tech 50: 804-810.

Ben Moumen A, Mansouri F, Richard G, et al. 2015b. Variations in the phytosterol and tocopherol compositions and the oxidative stability in seed oils from four safflower (Carthamus tinctorius L) varieties grown in north-eastern Morocco. Inter Food Sci Tech 50: 2264-2270.

Blakeney AB, Harris PJ, Henry RJ, Stone BA. 1983. A simple and rapid preparation of alditol acetates for monosaccharide analysis. Carbohydr Res 113: 291-299.

Bowles VG, Mayerhofer R, Davis C, Good AG, Hall JC. 2010. A phylogenetic investigation of Carthamus combining sequence and microsatellite data. Plant Syst Evol 287: 85-97.

Bradford MM. 1976. A rapid and sensitive method for the quantitation of microgram quantities of protein utilizing the principle of protein-dye binding. Anal Biochem 72: 248-254.

Chapeland-Leclerc F, Papon N, Noël T, Villard J. 2005. Moisissures et risques alimentaires (mycotoxicoses). Rev Francoph Lab 2005: 61-66.

Dessie J, Melaku S, Tegegne F, Peters KJ. 2010. Effect of supplementation of Simada sheep with graded levels of concentrate meal on feed intake, digestibility and body-weight parameters. Trop Anim Health Prod 42: 841-848.

Dixon R, Hosking B, Egan A. 2003a. Effects of oilseed meal and grain-urea supplements fed infrequently on digestion in sheep: 1 . Low quality grass hay diets. Anim Feed Sci Tech 110: 75-94.

Dixon R, Karda W, Hosking B, Egan A. 2003b. Effects of oilseed meals and grain-urea supplements fed infrequently on digestion in sheep: 2. Cereal straw diets. Anim Feed Sci Tech 110: 95-110.

Dubois V, Breton S, Linder M, Fanni J, Parmentier M. 2007. Fatty acid profiles of 80 vegetable oils with regard to their nutritional potential. Eur J Lipid Sci Technol 109: 710-732.

Food and Agriculture Organisation of the United Nations. 2017. FAO Statistical Databases. Available from http://faostat3.fao.org (last consult: 2017/10/03).

Farran M, Barbour G, Usayran N, Kayouli C. 2010. Metabolizable energy and amino acid digestibility of decorticated extruded safflower meal 1. Poult Sci 89: 1962-1966.

Galicia-González A, Goytortúa-Bores E, Palacios E, et al. 2010. Chemical composition and digestibility of three mexican safflower meals used as ingredients in diets for whiteleg shrimp, Litopenaeus vannamei. J World Aquac Soc 41: 191-202.
Garg M, Kannan A, Shelke S, Phondba B, Sherasia P. 2012. Nutritional evaluation of some ruminant feedstuffs by in vitro gas production technique. Indian J Anim Sci 82: 898.

Gibbins RD, Aksoy HA, Ustun G. 2012. Enzyme-assisted aqueous extraction of safflower oil: optimisation by response surface methodology. Inter Food Sci Tech 47: 1055-1062.

Gowda NKS, Ramana JV, Prasad CS, Singh K. 2004. Micronutrient content of certain tropical conventional and unconventional feed resources of southern India. Trop Anim Health Prod 36: 77-94.

Hinton DG. 2007. Supplementary feeding of sheep and beef cattle. Melbourne (Australia): Landlinks Press.

Knowles P. 1955. Safflower-production, processing and utilization. Econ Bot 9: 273-299.

Mariod AA, Ahmed SY, Abdelwahab SI, et al. 2012. Effects of roasting and boiling on the chemical composition, amino acids and oil stability of safflower seeds. Inter Food Sci Tech 47: 1737-1743.

Movahhedy-Dehnavy M, Modarres-Sanavy SAM, Mokhtassi-Bidgoli A. 2009. Foliar application of zinc and manganese improves seed yield and quality of safflower (Carthamus tinctorius L.) grown under water deficit stress. Ind Crop Prod 30: 82-92.

Nagaraj G. 1995. Quality And Utility Of Oilseed. Hyderabad (India): Directorate of Oilseeds Research.

Nosheen A, Bano A, Yasmin H, et al. 2016. Protein quantity and quality of safflower seed improved by NP fertilizer and Rhizobacteria (Azospirillum and Azotobacter spp.). Front Plant Sci 7: 1-12. DOI: 10.3389/fpls.2016.00104.

Sammour RH. 1999. Proteins of linseed (Linum usitatissimum L.), extraction and characterization by electrophoresis. Bot Bull Acad Sinica 40: 121-126.

Scheel K. 1936. Colorimetric determination of phosphoric acid in fertilizers with the Pulfrich photometer. ZAnal Chem 105: 256-269.

Senkal BC, Kiralan M, Ramadan MF. 2016. Impact of harvest times on the quality characteristics of oils recovered from different safflower (Carthamus tinctorius) cultivars sown in spring and autumn. Eur Food Res Technol 242: 371-381.

Smith JR. 1996. Safflower. Champaign (Illinois): AOCS Press.

Ustaoglu Tiril S, Kerim M. 2015. Evaluation of safflower meal as a protein source in diets of rainbow trout [Oncorhynchus mykiss, Walbaum, 1792]. J Appl Ichthyol 31: 895-899.

Van Soest PJ. 1963. Use of detergents in the analysis of fibrous feeds. 2. A rapid method for the determination of fiber and lignin. J AOAC Inter 46: 829-835.

Van Soest PJ. 1967. Use of detergents in the analysis of fibrous feeds. IV. Determination of plant cell wall constituents. $J$ Assoc Offic Anal Chem 50: 50-55.

Zraibi L, Kajeiou M, Caid HS, Nabloussi A. 2014. Safflower evaluation under contrasted environment conditions and selection of promising genotypes. J Agric Sci Technol B 4: 299-311.

Zraibi L, Nabloussi A, Kajeiou M, Elamrani A, Khalid A, Serghini Caid H. 2011. Comparative germination and seedling growth response to drought and salt stresses in a set of safflower (Carthamus tinctorius) varieties. Seed Technol 33: 40-52.

Cite this article as: Mansouri F, Ben Moumen A, Richard G, Fauconnier M-L, Sindic M, Elamrani A, Serghini Caid H. 2018. Proximate composition, amino acid profile, carbohydrate and mineral content of seed meals from four safflower (Carthamus tinctorius L.) varieties grown in north-eastern Morocco. OCL 25(2): A202. 